\title{
Mechanism of Action of Homocysteine and Its Thiolactone in Hemostasis System
}

\author{
K. KAROLCZAK, B. OLAS \\ Department of General Biochemistry, Institute of Biochemistry, University of Lodz, Lodz, Poland
}

Received March 27, 2008

Accepted September 8, 2008

On-line November 4, 2008

\begin{abstract}
Summary
In the article, the actions of homocysteine (Hcys) and its metabolite - cyclic thioester - homocysteine thiolactone (HTL) on complex process of hemostasis, which regulates the flowing properties of blood, are described. Possible interaction of Hcys and HTL with endothelial cells, blood platelets, plasmatic fibrinogen and plasminogen, as the important major components of hemostasis are also discussed. The modification of hemostatic proteins ( $\mathrm{N}$-homocysteinylated or S-homocysteinylated proteins) induced by Hcys or its thiolactone, and links of homocysteine or homocysteine thiolactone to $\mathrm{NO}$ metabolism seem to be the main reason of biotoxicty of homocysteine in cardiovascular diseases.
\end{abstract}

\section{Key words}

Homocysteine $\bullet$ Homocysteine thiolactone $\bullet$ Hemostasis

\section{Corresponding author}

Beata Olas, Department of General Biochemistry, Institute of Biochemistry, University of Lodz, Banacha 12/16, 90-237 Lodz, Poland. E-mail: olasb@biol.uni.lodz.pl

\section{Introduction}

Hemostasis is a complex process that regulates the flowing properties of blood in vivo. Classical primary and secondary hemostasis only comprised the sequential formation of the white and red thrombus, but there is growing awareness that hemostasis is intimately coupled to fibrinolytic processes, inflammatory reactions as well as to initiation of angiogenesis and wound healing. Basically, three components need to interact to assure effective primary and secondary hemostasis together with the normal sequelae, fibrinolysis and tissue repair: 1) the vascular wall (smooth muscle, matrix and connective tissue, endothelial cells), 2) formed elements of the blood (blood platelets, granulocytes, monocytes, lymphocytes), and 3) the plasmatic clotting and fibrinolytic systems (Becker et al. 2000). Hemostatic abnormalities can lead to excessive bleeding, thrombosis or other cardiovascular diseases. Recently, it has been shown that homocysteine (Hcys), which is an intermediate formed during the catabolism of the essential dietary amino acid methionine induces changes in hemostasis, including blood clotting and fibrinolysis (Perla-Kajan et al. 2007). Elevated level of Hcys may disrupt functions of the vascular endothelium, changing the character of its surface from anticoagulant to procoagulant (Jacobsen 1998, PerlaKajan et al. 2007). This review describes the chemical structure and biological activities of homocysteine and its cyclic thioester - homocysteine thiolactone (HTL) and their effects on hemostasis process.

\section{Chemical structure and function of homocysteine and its metabolites}

Homocysteine is involved in convertions of methionine (Met) and cysteine (Cys). The immediate precursor of Hcys is S-adenosylhomocysteine (SAH), which is hydrolyzed by SAH hydrolase to homocysteine and adenosine. In the next step homocysteine is remethylated to methionine by methionine synthase or betaine:homocysteine methyltransferase. Moreover, Hcys enters the transulfuration pathway and is converted into 
cystathionine $\beta$-synthase and cystathionine $\gamma$-lyase. This process is present only in the liver, kidney, pancreas and small intestine (Brosnan et al. 2004, Perla-Kajan et al. 2007). Homocysteine may also enter the first step of protein synthesis. Because structural similarity of Hcys to Met, homocysteine may be recognized and activated by methionyl-tRNA synthetase. However, error-editing activity of methionyl-tRNA synthetase does not allow homocysteine to be incorporated into proteins. As a product of the editing reaction homocysteine thiolactone is formed (Jakubowski and Fersht 1981, Jakubowski 2003, 2004, Perla-Kajan et al. 2007). The chemical structure of Hcys and its thiolactone is presented in Figure 1. Homocysteine metabolism depends on the level of vitamins (folic acid, vitamin $\mathrm{B}_{6}$ and $\mathrm{B}_{12}$ ) as cofactors for the enzymes involved in Hcys turnover. In human blood homocysteine may exist in free or protein bound forms as N-homocysteinylated (N-Hcys-protein) or S-homocysteinylated proteins (S-Hcys-protein), that were described as N-Hcys-hemoglobin, N-(Hcys-S-S-Cys)albumin, S-Hcys-albumin, and cysteinylhomocysteine (Cys-Hcys)) (Jakubowski 2002, 2005, 2006, Chwatko and Jakubowski 2005a,b, Perla-Kajan et al. 2007). Mechanism of N-homocysteinylation involves acylation of Lys $\varepsilon$-amino group by the activated carboxyl group of HTL (Jakubowski 2003，2004，2005，2006), whereas S-homocysteinylation is induced by Hcys (Fig. 1). In human plasma some various hemostatic proteins are S-homocysteinylated, for example coagulation factor Va (Undas et al. 2001). N-homocysteinylated proteins in human plasma represent from 0.3 to $23 \%$ of total homocysteine. Small amounts of N-Hcys-proteins are also found in different hemostatic proteins (antitrypsin, fibrinogen) (Jakubowski 2002). These modifications may lead to impairment of protein functions. Approximately $80 \%$ of plasma homocysteine is protein bound, and only a small amount exists as a free reduced homocysteine. The majority of the unbound portion of Hcys is oxidized to form dimers (homocystine) or combined with cysteine to form mixed disulphides (Jakubowski 2002, 2005, 2006, Chwatko and Jakubowski 2005a,b, Perla-Kajan et al. 2007). Plasma Hcys level is determined by multiple factors, like genetic, demographic, acquired, and lifestyle determinants. Total plasma Hcys concentration for healthy adults is in the range of 5-15 $\mu \mathrm{M}$. Patients with mild hyperhomocysteinemia have 15-25 $\mu \mathrm{M}$ Hcys (PerlaKajan et al. 2007). In urine after oxidation of Hcys is referred to as homocystinuria. Thus, for abnormal metabolism of Hcys, the blood can be analyzed. Mild
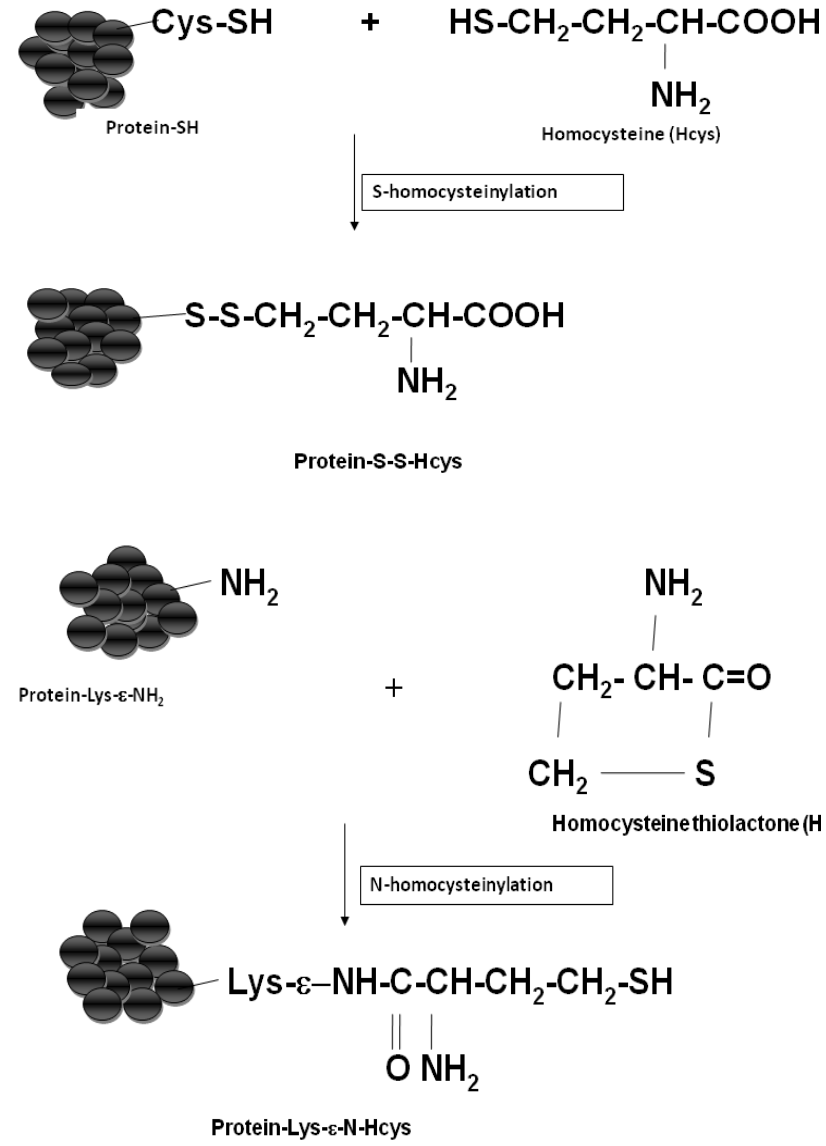

Fig. 1. The chemical structure of homocysteine (Hcys) and its thiolactone (HTL), mechanism of $\mathrm{N}$ - and $\mathrm{S}$-homocysteinylation of proteins.

hyperhomocysteinemia is an independent risk factor for atherosclerotic disease, deep vein thrombosis and thromboembolism. Elevated Hcys levels promote thrombosis, although the mechanism by which Hcys exerts its prothrombotic effect remains unclear. Moreover, homocysteine metabolites (thiolactone) and protein homocysteinylation formed in plasma, are implicated in different cardiovascular diseases (Thambyrajah et al. 2000, Yang et al. 2006).

\section{The effect of homocysteine and its thiolactone on endothelial cells}

At cellular level pathological role of homocysteine seems to be associated with an alteration of endothelial cells, which play an important role in hemostasis. Endothelial cells are very sensitive even to a mild increase of Hcys concentration. This sensitivity may be explained by the fact, that human endothelial cells do not express active form of cystathionine $\beta$-synthase and consequently can not initiate homocysteine catabolism 
through transsulfuration pathway (Jacobsen 1998). Elevated level of Hcys may modulate functions of the vascular endothelium, changing the character of its surface from anticoagulant to procoagulant (Jacobsen 1998). Endothelial anticoagulant pathway is based on heparin-like glycosaminogycan-antithrombin III interaction. Rodgers et al. (1986) showed that after incubation of endothelium with Hcys the activity of coagulation factor $\mathrm{V}$ increases. Coagulation factor $\mathrm{V}$ in Hcys-modified endothelium is cleaved in fragments different than those obtained after factor $\mathrm{V}$ cleavage by thrombin or coagulation factor Xa (Rodgers et al. 1986). Moreover, in hyperhomocysteinemia the prothrombotic tendency may be related to impaired inactivation of S-homocysteinylated coagulation factor $\mathrm{Va}$ by activated protein C (Undas et al. 2001). However, Hcys and its thiolactone have no effect on factor $\mathrm{V}$ activation by thrombin. It was showed that factor $\mathrm{V}$ incubated with $\left[{ }^{35}\right.$ S ]homocysteine $(10-450 \mu \mathrm{M})$ incorporated label within 5 min, which was found only in those fragments that contained free sulfhydryl groups: the light chain (Cys1960, Cys-2113), the B region (Cys-1085), and the $26 / 28-\mathrm{kDa}$ (residues 507-709) activated protein C cleavage products of the heavy chain (Cys-539, Cys-585). On the other hand, Lentz et al. (2002) suggested that activation of protein $\mathrm{C}$ by thrombin and inactivation of factor $\mathrm{Va}$ by activated protein $\mathrm{C}$ are not impaired during moderate hyperhomocysteinemia in vivo in monkeys. Another studies showed the effect of Hcys on activity of thrombomodulin, which is involved in blood clotting.

It has been demonstrated that not only Hcys, but also HTL may modulate properties and functions of endothelial cells. Raposo et al. (2004) indicated that both compounds - Hcys and its thiolactone inhibit the activity of lysyl oxidase (an enzyme involved in extracellular matrix maturation) in vascular endothelial cells. Jakubowski (2000) showed that N-homocysteinylation exists in endothelial cell proteins, and this process depends on the concentration of Hcys. Modification of endothelial cell proteins may cause different pathophysiological consequences, such as modulation of hemostasis system, which may contribute to cardiovascular diseases.

\section{Homocysteine and nitric oxide}

Nitric oxide ( $\left.{ }^{\circ} \mathrm{NO}\right)$ plays an important role in a number of physiological processes. It is well known that vascular endothelial cells produce ${ }^{\bullet}$ NO. However, other cells, which are involved in hemostasis - blood platelets may also synthesize ${ }^{\circ} \mathrm{NO}$ and platelet ${ }^{\circ} \mathrm{NO}$ synthase (NOS) has been identified by Muruganadam and Mutus (1994). Two main NOS isoforms have been isolated: calcium-independent inducible NOS (iNOS) and a calcium/calmodulin-dependent endothelial NOS (eNOS) (Mehta et al. 1995). 'NO is released by NOS action from the guanidine moiety of L-arginine, yielding $\mathrm{NO}$ and citrulline. ${ }^{\circ} \mathrm{NO}$ is very simple free radical which play important regulatory role in many tissues, but originally •NO was identified as a factor influenced mainly human vascular system. ${ }^{\circ} \mathrm{NO}$ has been implicated in a number of cardiovascular diseases and every risk factor appears to be associated with a reduction in endothelial generation of ${ }^{\bullet} \mathrm{NO}$.

Evidences of some cooperation between homocysteine and ${ }^{\circ} \mathrm{NO}$ in vascular system pathogenesis originate from physiological, cellular and genetic reports. Patients from population with NOS3 894TT genotype (mutation in gene for nitric oxide synthase) have a tendency to higher Hcys concentration in the blood. Mentioned tendency was especially distinct in subpopulation of NOS3 894TT patients who had low foliate levels. However, there was no close correlation between NOS3 894TT genotype and Hcys plasma levels (Brown et al. 2003). The question is how Hcys can modulate $\mathrm{NO}$ synthase. First thought is that Hcys may influence on NOS activity. Transformation of radiolabeled arginine to citrulline catalyzed by nitric oxide synthase is unchanged after renal arterial endothelium incubation with Hcys $(40 \mu \mathrm{M})$ in comparison with control cells. Also after incubation of endothelial cells with Hcys (10, 20 and $50 \mu \mathrm{M}$ for $24 \mathrm{~h}$ ) NOS activity was untouched (Fatini et al. 2005). Despite the fact that NOS activity also seemed to be normal during hyperhomocysteinemia in vitro, level of ${ }^{\circ} \mathrm{NO}$ under such conditions is definitely lower and this effect is directly proportional to Hcys plasma level (Becker et al. 2005). One of possible way of NOS activity regulation by Hcys is action through direct dimethylarginine dimethylaminohydrolase (DDAH) binding via disulfide bounds and further asymmetric dimethylarginine (ADMA) accumulation, what disrupts NOS activity (Stühlinger et al. 2001). Similar observations confirming ADMA accumulation during hyperhomocysteinemia has been done in animal models (Akhand et al. 1999). The same authors have observed in vitro that ADMA secretion by human endothelial cells after stimulation by Hcys can be stopped (for $24 \mathrm{~h}$ by using S-adenosylhomocysteine methylation inhibitor). 
The main molecules responsible for decrease of NO level in hyperhomocysteinemic patients are probably reactive oxygen species (ROS). Hcys can enhance ROS production (Li et al. 2002, Fischer et al. 2003, Fatini et al. 2005) - the generation of superoxide anion $\left(\mathrm{O}_{2}^{-\bullet}\right)$ in reaction catalyzed by NADPH oxidase (Becker et al. 2005). Fischer et al. (2003) showed the increased of protein nitration (induced by peroxynitrite, which is produced in the reaction of ${ }^{\bullet} \mathrm{NO}$ with $\mathrm{O}_{2}^{-\bullet}$ ).

\section{The effect of homocysteine and its thiolactone on blood platelets}

Blood platelets are multiresponding cells, both with respect to the number of agonists and number of responses. They can be activated by different compounds including coagulation factors (thrombin), hormones (epinephrine, vasopresin), low-molecular-weight substances (serotonin, adenosine diphosphate (ADP)), lipid derivatives (platelet aggregating factor (PAF), thromboxane $\mathrm{A}_{2}\left(\mathrm{TXA}_{2}\right)$ ), and other protein substances (collagen or immune complexes). The response of platelet to agonists, which is called platelet activation, includes mainly adhesion (to foreign surfaces such as collagen or glass), shape change, aggregation and secretion of active compounds from three different storage granules (dense granules, $\alpha$-granules and lysosomes), shedding of microvesicles, formation of platelet procoagulant activity and retraction of fibrin clots (Wu 1996, Levy-Toledano 1999, Ryningen and Holmsen 1999). Increased platelet activation with hyperaggregability is one of the risk factors in pathogenesis of different cardiovascular disease. Blood platelets obtained from patients with peripheral occlusive arterial disease, with associated hyperhomocysteinemia, are far more reactive and sensitive for agonists, but also far less sensitive for inhibitors (Riba et al. 2004). In diabetic patients a high level of Hcys levels is associated with more potent platelets aggregation (Rajkumar et al. 1999). Signorello et al. (2007) observed that Hcys induces oxidative stress, inhibits nitric oxide formation in platelets from type 2 diabetic patients, and may promote platelet hyperactivity and various cardiovascular diseases. Moreover, Hcys stimulates the calcium mobilization in platelets from type 2 diabetic patients (Alexandru et al. 2008). Mohan et al. (2008) suggested that platelet activation and hypercoagulability occur after exposure to Hcys, especially in patients with critical limb ischemia. Hcys concentrations of approximately $50 \mu \mathrm{M}$ appear to be the level at which these changes occur in vitro, and this effect on platelets appears to be indirect. In animal model with hyperhomocysteinemia (induced by diet poor of folic acid), the aggregation of platelets stimulated by ADP or thrombin is higher than in control animals (Durand et al. 1996). The direct action of Hcys on blood platelets is unknown and sometimes controversial. Some studies demonstrated that homocysteine promotes arachidonic acid release, thromboxane $\mathrm{A}_{2}$ formation (Signorello et al. 2002, 2007) and protein tyrosine phosphorylation in blood platelets (Leoncini et al. 2006). Undas et al. (2007) demonstrated that elevated total Hcys is associated with increased platelet activation at the site of microvascular injury. McDonald et al. (1964) showed increased platelet adhesion in homocysteinuric patients. However, there is no evidence of a direct in vitro effect of homocysteine on platelet adhesion (Uhlemann et al. 1976) or aggregation (Stamler et al. 1993). Our preliminary studies have reported that reduced form of Hcys slightly stimulated platelet aggregation induced by a physiological agonist thrombin (Olas et al. 2008). We also observed that HTL alone did not induce platelet aggregation, but HTL, similarly as Hcys, increased platelet aggregation induced by thrombin (Olas et al. 2008). Platelet aggregation induced by HLT is followed by thromboxane $\mathrm{A}_{2}$ synthesis and secretion (McCully and Carvalho 1987). McGarrigle et al. (2006) showed that Hcys and HTL promote activation of platelet integrin $\alpha_{\mathrm{IIb}} \beta_{3}$, that is involved in platelet adhesion or aggregation. On the other hand, Luo et al. (2006) observed that Hcys potentiates collagen type I induced-platelet activation through signaling components of glycoprotein VI and integrin $\alpha_{2} \beta_{1}$ pathway. Prontera et al. (2007) indicate that a potential molecular target of Hcys is the CD40/CD40L system in platelets; and upregulation of CD40/CD40L signaling may represent a link between hyperhomocyteinemia and an increased risk of cardiovascular diseases.

Blood platelets, in analogy to other circulating blood cells, can generate different reactive oxygen/nitrogen species (ROS/RNS) that may behave as second messengers and may regulate platelet functions. Several sources of ROS are postulated in blood platelets (Pignatelli et al. 1998, Wachowicz et al. 2002, Krotz et al. 2004). Intracellular sources of reactive oxygen species in platelets are arachidonic acid pathway (via cyclooxygenase or 12-lipoxygenase) stimulated by different agonists, the glutathione cycle (Jahn and Hansch 1990, Pignatelli et al. 1998) and metabolism of phosphoinositides (Gopalakrishna et al. 2000, 
Wachowicz et al. 2002). ROS are generated in platelets mostly by activation of NAD(P)H oxidase (Forde and Fitzgerald 1997, Krotz et al. 2004, Begonja et al. 2005) and xanthine oxidase (Miller et al. 1993). Our recent data, when we used the method of cytochrome c reduction for the estimation of the level of $\mathrm{O}_{2}{ }^{\bullet}$ showed that not only Hcys, but also HTL induces the production of $\mathrm{O}_{2}^{-{ }^{-}}$in resting and thrombin-activated platelets (Olas et al. 2008).

In blood platelets peroxynitrite may be formed (Lufrano and Balazy 2003). It has been demonstrated that reaction of protein with $\mathrm{ONOO}^{-}$resulted in the nitration and oxidation of some amino acid residues (HernandezHernandez et al. 1999, Olas and Wachowicz 2007). Free and protein-bound 3-nitrotyrosine, a stable product of tyrosine nitration, may be measured as a biomarker of protein damage induced by peroxynitrite and other reactive nitrogen species (Forde and Fitzgerald 1997, Begonja et al. 2005), since peroxynitrite nitrates tyrosine residues in different proteins in vivo and in vitro (Miller et al. 1993). During platelet activation spontaneous nitration of proteins may also take place, without the addition of exogenous peroxynitrite (Muruganandam and Mutus 1994). When proteins from activated and resting platelets were separated on gels and immunoblotted with antinitrotyrosine antibodies, a number of proteins in the low molecular weight region were nitrated. Moreover, we observed that reduced form of Hcys and HTL distinctly reduced nitration of platelet proteins (Olas et al. 2008). It is suggested that the nitrosation of homocysteine or its metabolite - HTL in blood platelets may exist. Nitrosation of Hcys may be responsible for a decrease in the level of ${ }^{\circ} \mathrm{NO}$, because Hcys reacts with ${ }^{\circ} \mathrm{NO}$ to form S-nitroso-homocysteine (Ignarro and Gruetter 1980). Signorello et al. (2007) showed that in type 2 diabetic patients high plasma Hcys is associated with increased platelet ROS level and reduced ${ }^{\circ} \mathrm{NO}$ formation in blood platelets. On the other hand, Hcys induces cell death in H9C2 cardiomyocytes through the generation of peroxynitrite and can activate key signaling cascades in the myocardium (Levrand et al. 2007). Moreover, Erol et al. (2007) have showed that Hcys increases ${ }^{\circ} \mathrm{NO}$ release from stimulated coronary microvascular endothelial cells without affecting basal "NO production, which is probably accompanied by increased production of reactive oxygen species. It can be postulated that endothelial cells generate ${ }^{\circ} \mathrm{NO}$ in order to minimize the damage caused by Hcys. There is a possibility that nitration of tyrosine may directly inhibit the tyrosine phosphorylation of proteins, which is well-recognized mechanism of signal transduction in blood platelets (Ischiropoulos 2003). It was showed that the addition of peroxynitrite to platelets, at relatively high concentrations, brought about the nitration of proteins and a rapid increase in the phosphorylation of tyrosine residues (Mondoro et al. 1997). However, if platelets were activated by the low doses of thrombin, the amount of phosphorylation was decreased; if high doses of thrombin were used, peroxynitrite caused the increase of the phosphorylation. There is no direct evidence that phosphorylation and nitration occur on the same proteins. Probably the relationship between nitration and tyrosine phosphorylation is a competitive process (Low et al. 2002). Marcondes et al. (2006) suggested that nitration of $\alpha$-actinin interferes with its phosphorylation and contributes consequently to the inhibitory role of ${ }^{\circ} \mathrm{NO}$ on platelet adhesion. Some results showed that homocysteine stimulates the tyrosine phoshorylation and activation of platelet phospholipase $\mathrm{C} \gamma 2$ (Leoncini et al. 2003) and Src kinase (Luo et al. 2006). The stimulation of this pathway by Hcys requires signals through oxygen free radicals and thromboxane $\mathrm{A}_{2}$. It is possible that the same mechanism may exist when blood platelets are treated with thiolactone homocysteine.

\section{Homocysteine, coagulation and fibrinolysis}

Fibrinogen is the main substrate for coagulation cascade and form a polymerized fibrin clot. Fibrinogen is a $340 \mathrm{kDa}$ glycoprotein, consisting of three pairs of nonidentical polypeptide chains, $\mathrm{A} \alpha, \mathrm{B} \beta$ and $\gamma$, interconnected by disulfide bonds. In the course of blood coagulation, fibrinogen, after the thrombin-induced cleavage of short fibrinopeptides A and B from the amino termini of $\alpha$ and $\beta$ chains, is converted to fibrin monomers. The monomers thereafter interact spontaneously and form half-staggered protofibrils flowed by the laterally associated fibers. The initial clot is stabilized by the formation of covalent cross-links in a reaction catalyzed by activated coagulation factor XIII. Fibrinogen and other plasma proteins can be covalently modified by Hcys or its thiolactone. Lysine homocysteinylation is a plausible mechanism for protein modification in vivo; and is likely an important pathogenic mechanism. Mass spectrometric analysis of fibrinogen treated with Hcys revealed twelve lysines that were homocysteinylated. Several of them are close to tissue plasminogen activator (tPA) and plasminogen 


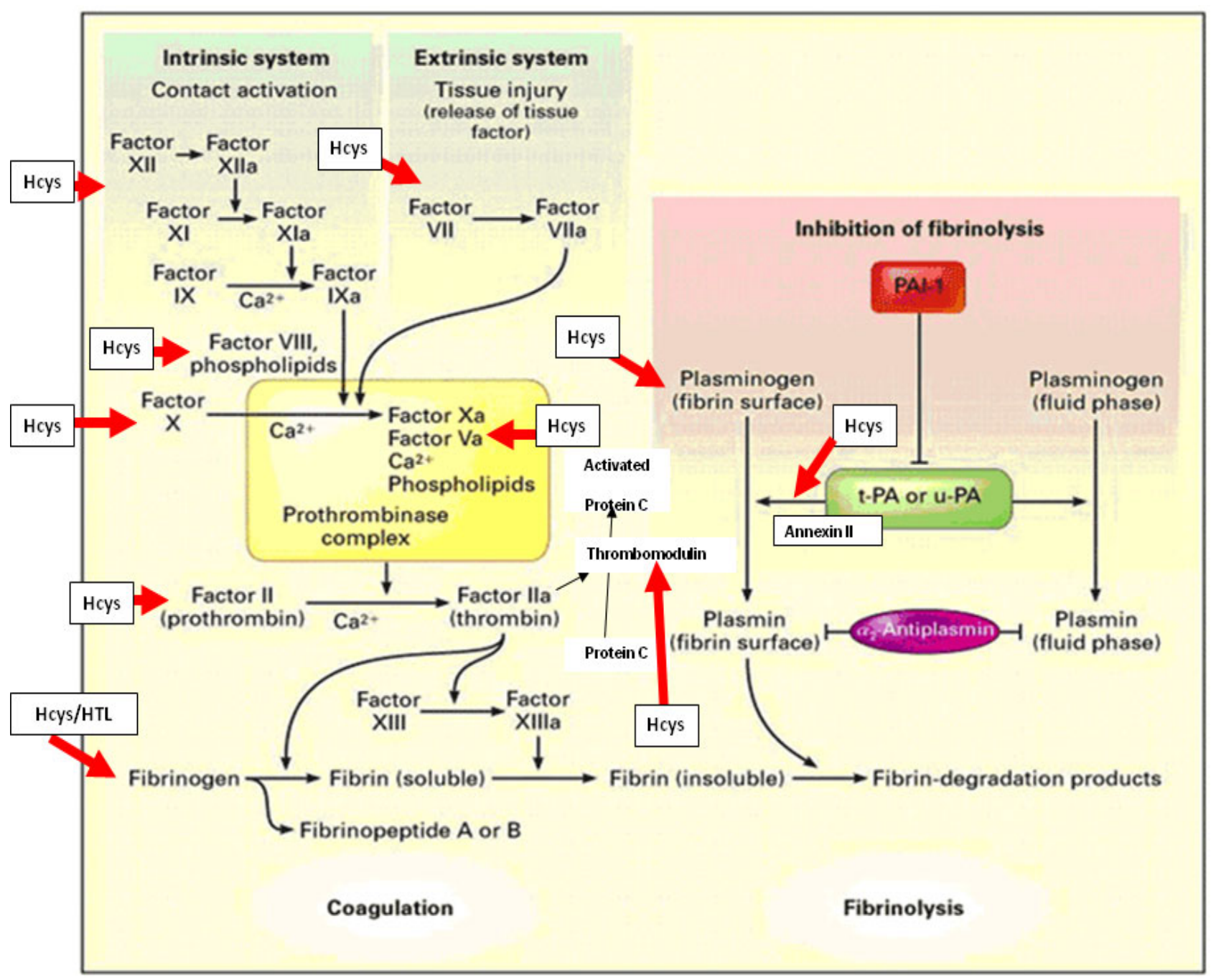

Fig. 2. Proposed targets of homocysteine (Hcys) and its thiolactone (HTL) action on coagulation and fibrinolysis.

binding sites. Moreover, lysines are major binding sites for fibrinolytic enzymes and are also sites of plasmin cleavage (Sauls et al. 2003, 2005, 2006, 2007). Sauls et al. (2007) suggest that homocysteinylation of lysine residues in fibrinogen may be linked to three important functional consequences. First, modification in the $\alpha \mathrm{C}$ domain could alter the lateral association of fibers and thereby alter clot structure. Second, the alteration of the protein conformation may interfere with calcium binding, which could contribute to alterations in fibrin clot structure. Third, modification of lysine sites that are directly involved in fibrinolytic enzyme binding and activity could lead to increased resistance to fibrinolysis the process by which a fibrin clot is dissolved. Recent reports showed that compounds with thiol groups enhance plasma factor XIII-mediated fibrinogen crosslinking. Since Hcys-SH is involved in oxide-reduction reactions or disulfide exchange reactions, it is possible that some components of fibrin formation such as fibrinogen and coagulation factor XIII can be altered. Lauricella et al. $(2002,2006)$ observed that clots formed from human plasma incubated in vitro with Hcys have a more compact structure, with shorter and more frequently branched fibers, than those formed in the absence of Hcys. Harpel et al. (1992) showed that Hcys enhances the binding of lipoprotein(a) to fibrin, and this results may suggest a biochemical relationship between thiol compound metabolism, thrombosis and atherogenesis.

In mildly hyperhomocysteinemic human subjects dysfibrinogenemia (which is characterized by formation of clots composed of abnormally thin, tightly packed fibers with an increased resistance to fibrinolysis) could play a role in the increased risk of atherothrombotic disease (Undas et al. 2006, Souls et al. 2007). On the other hand, Lijfering et al. (2007) showed that the increased risk of cardiovascular diseases in hyperhomocysteinemia is mainly related to elevated levels of coagulation factor VIII. Moreover, Ebbesen and 


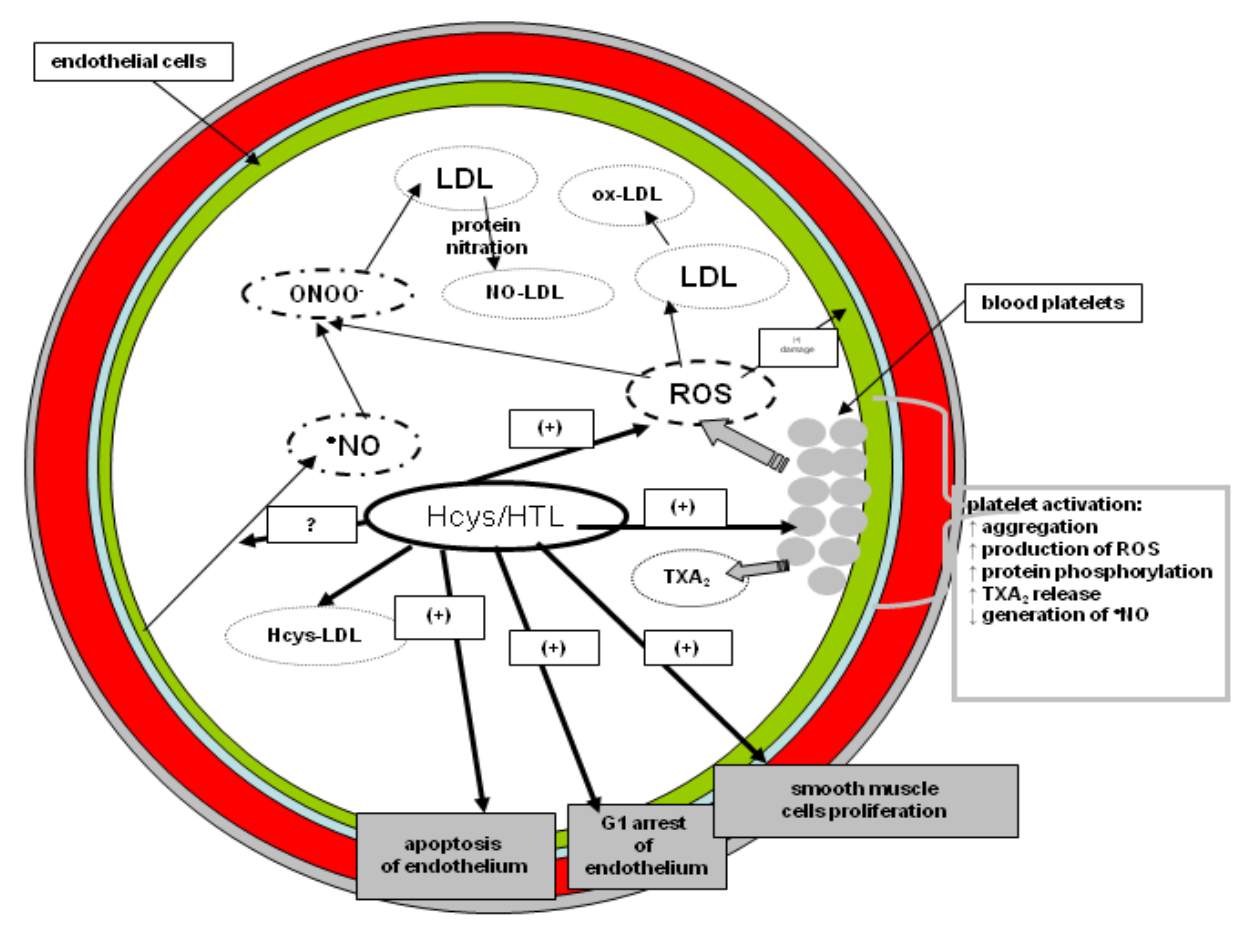

Fig. 3. Proposed model for the regulatory role of Hcys and HTL in vascular well (smooth muscle, endothelial cells) and in blood platelets.

Hcys - homocysteine

$\mathrm{HTL}$ - homocysteine thiolactone

LDL - low density lipoproteins

Hcys-LDL - homocysteinylated LDL ox-LDL - oxidized LDL

ROS - reactive oxygen species

-NO - nitric oxide

$\mathrm{ONOO}^{-}$- peroxynitrite

NO-LDL - nitrated LDL

$\mathrm{TXA}_{2}$ - thromboxane $\mathrm{A}_{2}$

Ingerslev (2005) found reduced functional activities of coagulation factors XII, X and II in hyperhomocysteinemia-induced by folate deficiency in rat, whereas the functional factor VII activity was unchanged. On the contrary, Al-Obaidi et al. (2000) observed that levels of coagulation factor VIIa and Hcys correlate in plasma of patients with acute coronary syndrome. These changes may enhance risk of thrombotic events in hyperhomocysteinemic patients. Recent reports showed that activity of antithrombin, which is one of the most important inhibitors of blood coagulation, is inhibited by HTL (Gugliucci 2008). Proposed targets of Hcys and HTL action on coagulation and fibrinolysis process are presented in Figure 2.

\section{Conclusions}

The mechanism of homocysteine and its thiolactone action on hemostasis process is complex and still unclear. Hcys or HTL may modulate the signal transduction in different cells and sometimes act in opposite ways. Homocysteine and its metabolite cause the changes in the level of reactive oxygen species and reactive nitrogen species (special ${ }^{\circ} \mathrm{NO}$ ) and may be responsible for the modification of hemostasis induced by these compounds (Fig. 3). The biological significance of hemostatic protein modification (fibrinogen and other coagulation factors) induced by Hcys or HTL is not well known, although especially N-homocysteinylation induced by HTL may play an important role in different pathophysiological consequences leading to cardiovascular diseases.

\section{Conflict of Interest}

There is no conflict of interest.

\section{Acknowledgements}

This work was supported by grant 506/810 from University of Lodz.

\section{References}

AKHAND AA, PU M, SENGA T, KATO M, SUZUKI H, MIYATA T, HAMAGUCHI M, NAKASHIMA I: Nitric oxide controls src kinase activity through a sulfhydryl group modification-mediated Tyr-527-independent and Tyr-416-linked mechanism. J Biol Chem 274: 25821-25826, 1999.

ALEXANDRU N, JARDIN I, POPOV D, SIMIONESCU M, GARCIA-ESTAN J, SALIDO GM, ROSADO JA: Effect of homocysteine on calcium mobilisation and platelet function in type 2 diabetes mellitus. J Cell Mol Med 12: 2015-2026, 2008. 
AL-OBAIDI MK, PHILIPPOU H, STUBBS PJ, ADAMI A, AMERSEY R, NOBLE MM, LANE DA: Relationships between homocysteine, factor via, and thrombin generation in acute coronary syndromes. Circulation 101: 372-377, 2000.

BECKER A, VAN HINSBERGH VW, KOSTENSE PJ, JAGER A, DEKKER JM, NIJPELS G, HEINE RJ, BOUTER LM, STEHOUWER CD: Serum homocysteine is weakly associated with von Willebrand factor and soluble vascular cell adhesion molecule 1, but not with C-reactive protein in type 2 diabetic and non-diabetic subjects - the Hoorn study. Eur J Clin Invest 30: 763-770, 2000.

BECKER JS, ADLER A, SCHNEEBERGER A, HUANG H, WANG Z, WALSH E, KOLLER A, HINTZE TH: Hyperhomocysteinemia, a cardiac metabolic disease: Role of nitric oxide and the p22phox subunit of NADPH oxidase. Circulation 111: 2112-2118, 2005.

BEGONJA AJ, GAMBARYAN S, GEIGER J, AKTAS B, POZGAJOVA M, NIESWANDT B, WALTER U: Platelet $\mathrm{NAD}(\mathrm{P}) \mathrm{H}$ oxidase-generated ROS production regulates $\{\mathrm{alph}\} \mathrm{IIb}\{$ beta 3 integrin activation independent of the NO/cGMP pathway. Blood 106: 2757-2760, 2005.

BROSNAN JT, JACOBS RL, STEAD LM, BROSNAN ME: Methylation demand: a key determinant of homocysteine metabolism. Acta Biochim Pol 51: 405-413, 2004.

BROWN KS, KLUIJTMANS LA, YOUNG IS, WOODSIDE J, YARNELL JW, MCMASTER D, MURRAY L, EVANS AE, BOREHAM CA, MCNULTY H, STRAIN JJ, MITCHELL LE, WHITEHEAD AS: Genetic evidence that nitric oxide modulates homocysteine: The nos3 894tt genotype is a risk factor for hyperhomocystenemia. Arterioscler Thromb Vasc Biol 23: 1014-1020, 2003.

CHWATKO G, JAKUBOWSKI H: The determination of homocysteine-thiolactone in human plasma. Anal Biochem 337: 271-277, 2005a.

CHWATKO G, JAKUBOWSKI H: Urinary extraction of homocysteine thiolactone in humans. Clin Chem 51: 408-415, $2005 b$.

DUAN J, DAI S, FANG CX, SUN R, SHAVALI S, SHARMA SK, EBADI M, REN J: Phytoestrogen alpha-zearalanol antagonizes homocysteine-induced imbalance of nitric oxide/endothelin-1 and apoptosis in human umbilical vein endothelial cells. Cell Biochem Biophys 45: 137-145, 2006.

DURAND P, PROST M, BLACHE D: Pro-thrombotic effects of a folic acid deficient diet in rat platelets and macrophages related to elevated homocysteine and decreased n-3 polyunsaturated fatty acids. Atherosclerosis 121: 231-243, 1996.

EBBESEN LS, INGERSLEV J: Folate deficiency-induced hyperhomocysteinemia attenuates, and folic acid supplementation restores, the functional activites of rat coagulation factors XII, X, and II. J Nutr 135: 1836$1840,2005$.

EROL A, CINAR MG, CAN C, MURAT O, ULKER S, KOSAY S: Effect of homocysteine on nitric oxide production in coronary microvascular endothelial cells. J Endothel Cell Res 14: 157-161, 2007.

FATINI C, SOFI F, GORI AM, STICCHI E, MARCUCCI R, LENTI M, CASINI A, SURRENTI C, ABBATE R, GENSINI GF: Endothelial nitric oxide synthase -786T $>$ C, but not $894 \mathrm{G}>\mathrm{T}$ and $4 \mathrm{a} 4 \mathrm{~b}$, polymorphism influences plasma homocysteine concentrations in persons with normal vitamin status. Clin Chem 51: 1159-1164, 2005.

FISCHER PA, DOMINGUEZ GN, CUNIBERTI LA, MARTINEZ V, WERBA JP, RAMIREZ AJ, MASNATTA LD: Hyperhomocysteinemia induces renal hemodynamic dysfunction: is nitric oxide involved? $J$ Am Soc Nephrol 14: 653-660, 2003.

FORDE RC, FITZGERALD DJ: Reactive oxygen species and platelet activation in reperfusion injury. Circulation 95: 787-789, 1997.

GOPALAKRISHNA R, JAKEN S: Protein kinase C signaling and oxidative stress. Free Radic Biol Med 28: 13491361, 2000.

GUGLIUCCI A: Antithrombin activity is inhibited by acrolein and homocysteine thiolactone: protection by cysteine. Life Sci 82: 413-418, 2008.

HARPEL PC, CHANG VT, BORTH W: Homocysteine and other sulfhydryl compounds enhance the binding of lipoprotein(a) to fibrin: a potential biochemical link between thrombosis, atherogenesis, and sulfhydryl compound metabolism. Proc Natl Acad Sci USA 89: 10193-10197, 1992. 
HERNANDEZ-HERNANDEZ A, ANCHEZ-YAGUE J, MARTIN-VALMASEDA EM, LLIANILLO M: Oxidative inactivation of human and sheep platelet membrane-associated phosphotyrosine phosphatase activity. Free Radic Biol Med 26: 1218-1230, 1999.

IGNARRO LJ, GRUETTER CA: Requirement of thiols for activation of coronary arterial guanylate cyclase by glyceryl trinitrate and sodium nitrite: possible involvement of S-nitrosothiols. Biochim Biophys Acta 631: 221-231, 1980.

ISCHIROPOULOS H: Biological selectivity and functional aspects of protein tyrosine nitration. Biochem Biophys Res Commun 305: 776-783, 2003.

JACOBSEN DW: Homocysteine and vitamins in cardiovascular disease. Clin Chem 44: 1833-1843, 1998.

JAHN B, HANSCH GM: Oxygen radical generation in human platelets: depence of 12-lipoxygenase activity and on the glutathione cycle. Int Arch Allergy Appl Immunol 93: 73-79, 1990.

JAKUBOWSKI H: Homocysteine is a protein amino acid in humans. Implications for homocysteine-linked disease. J Biol Chem 277: 30425-30428, 2002.

JAKUBOWSKI H: Homocysteine-thiolactone and S-nitroso-homocysteine mediate incorporation of homocysteine into protein in humans. Clin Chem Lab Med 41: 1462-1466, 2003.

JAKUBOWSKI H: Molecular basis of homocysteine toxicity in humans. Cell Mol Life 61: 470-487, 2004.

JAKUBOWSKI H: Anti-N-homocysteinylated protein autoantibodies and cardiovascular disease. Clin Chem Lab Med 43: 1011-1014, 2005.

JAKUBOWSKI H: Pathophysiological consequences of homocysteine excess. J Nutr 136: 1741S-1749S, 2006.

JAKUBOWSKI H, FERSHT AR: Alternative pathway for editing noncognate amino acids by aminoacyl-tRNA synthases. Nucleic Acids Res 9: 3105-3117, 1981.

JAKUBOWSKI H, ZHANG L, BARDEGUEZ A, AVIV A: Homocysteine thiolactone and protein homocysteinylation in human endothelial cells: implications for atherosclerosis. Circ Res 87: 45-51, 2000.

KROTZ F, SOHN HY, POHL U: Reactive oxygen species, players in the platelet game. Arterioscler Thromb Vasc Biol 24: 1988-1996, 2004.

LAURICELLA AM, QUINTANA IL, KORDICH LC: Effects of homocysteine thiol group on fibrin networks: another possible mechanism of harm. Thromb Res 107: 75-79, 2002.

LAURICELLA AM, QUINTANA I, CASTANON M, SASSETTI B, KORDICH L: Influence of homocysteine on fibrin network lysis. Blood Coagul Fibrinolysis 17: 181-186, 2006.

LENTZ SR, PIEGORS DJ, FERNANDEZ JA, ARNING EE, MALINOW MR, GRIFFIN JH, BOTTIGLIERI T, HAYNES WG, HEISTAD DD: Effect of hyperhomocysteinemia on protein C activation and activity. Blood 100: 2108-2112, 2002.

LEONCINI G, PASCALE R, SIGNORELLO MG: Effects of homocysteine on 1-arginine transport and nitric oxide formation in human platelets. Eur J Clin Invest 33: 713-719, 2003.

LEONCINI G, BRUZZESE D, SIGNORELLO MG: Activation of p38MAPKinase/cPLA2 pathway in homocysteine treated platelets. J Thromb Haemost 4: 209-216, 2006.

LEONCINI G, BRUZZESE D, SIGNORELLO MG: A role for PLC $\gamma 2$ in platelet activation by homocysteine. $J$ Cell Biochem 100: 1255-1265, 2007.

LEVRAND S, PACHER P, PESSE B, ROLLI J, FAIHL F, WAEBER B, LIAUDET L: Homocysteine induces cell death in H9C2 cardiomyocytes through the generation of peroxynitrite. Biochem Biophys Res Commun 359: 445-450, 2007.

LEVY-TOLEDANO S: Platelet signal transduction pathways: could we organize them into a 'hierarchy'? Haemostasis 29: 4-15, 1999.

LIJFERING WM, VEEGER NJGM, BROUWER JLP, VAN DER MEER J: The risk of venous and arterial thrombosis in hyperhomocysteinemic subjects may be a result of elevated factor VIII levels. Haematologica 92: 1703-1706, 2007.

LOW SY, SABETKAR M, BRUCKDORFER KR, NASEEM KM: The role of protein nitration in the inhibition of platelet activation by peroxynitrite. FEBS Lett 511: 59-64, 2002.

LUO F, LIU X, WANG S, CHEN H: Effect of homocysteine on platelet activation induced by collagen. Nutrition 22: 69-75, 2006. 
MARCONDES S, CARDOSO MHM, MORGANTI RP, THOMAZZI SM, LILLA S, MURAD F, DE NUCCI G, ANTUNES E: Cyclic GMP-independent mechanisms contribute to the inhibition of platelet adhesion by nitric oxide donor: a role for $\alpha$-actinin nitration. Proc Natl Acad Sci USA 103: 3434-3439, 2006.

MCCULLY KS, CARVALHO AC: Homocysteine thiolactone, N-homocysteine thiolactonyl retinamide, and platelet aggregation. Res Commun Chem Pathol Pharmacol 56: 349-360, 1987.

MCDONALD L, BRAY C, FIELD C, LOVE F, DAVIES B: Homocystinuria, thrombosis and the blood platelets. Lancet 1: 745-746, 1964.

MCGARRIGLE SA, WALSH GM, O'NEILL S, MORAN N, COLLINS PB: Homocysteine and its thiolactone derivative promote activation of the platelet integrin $\alpha \operatorname{Ilb} \beta 3.8^{\text {th }} U K$ Platelet Meeting, Reading, 49, 2006.

MEHTA JL, CHEN LY, KONE CB, MEHTA P, TURNER P: Identification of constitutive and inducible forms of nitric oxide synthase in human platelets. J Lab Clin Med 125: 87-96, 1995.

MILLER DM, GROVER TA, NAYINI N, AUST SD: Xantine-oxidase- and iron-dependent lipid peroxidation. Arch Biochem Biophys 301: 1-7, 1993.

MOHAN IV, JAGROOP IA, MIKHAILIDIS DP, STANSBY GP: Homocysteine activates platelets in vitro. Clin Appl Thromb Hemost 14: 8-18, 2008.

MONDORO TH, SHAFER BC, VOSTAL JG: Peroxynitrite-induced tyrosine nitration and phosphorylation in human platelets. Free Rad Biol Med 22: 1055-1063, 1997.

MURUGANANDAM A, MUTUS B: Isolation of nitric oxide synthase from human platelets. Biochim Biophys Acta 1200: 1-6, 1994.

OLAS B, WACHOWICZ B: Role of reactive nitrogen species in blood platelet functions. Platelets 18: 555-565, 2007.

OLAS B, KEDZIERSKA M, WACHOWICZ B: Comparative studies on homocysteine and its metabolite homocysteine thiolactone action in blood platelets in vitro. Platelets 19: 520-527, 2008.

PERŁA-KAJAN J, TWARDOWSKI T, JAKUBOWSKI H: Mechanisms of homocysteine toxicity in humans. Amino Acids 32: 561-572, 2007.

PIGNATELLI P, PULCINELLI FM, LENTI L, GAZZANIGA PP, VIOLI F: Hydrogen peroxide is involved in collagen-induced platelet activation. Blood 91: 484-490, 1998.

PRONTERA C, MARTELLI N, EVANGELISTA V, D'URBANO E, MANARINI S, RECCHIUTI A, DRAGANI A, PASSERI C, DAVI G, ROMANO M: Homocysteine modulates the CD40/CD40L system. $J$ Am Coll Cardiol 49: 2182-2190, 2007.

RAJKUMAR V, RAGATZKI P, SIMA A, LEVY J: Enhanced platelet aggregation, high homocysteine level, and microvascular disease in diabetic muscle infarctions: Implications for therapy. Endocrine 11: 57-60, 1999.

RAPOSO B, RODRIGUEZ C, MARTINEZ-GONZALES J, BADIMON L: High levels of homocysteine inhibit lysyl oxidase (LOX) and downregulate LOX expression in vascular endothelial cells. Atherosclerosis 177: 1-8, 2004.

RIBA R, NICOLAOU A, TROXLER M, HOMER-VANIASINKAM S, NASEEM KM: Altered platelet reactivity in peripheral vascular disease complicated with elevated plasma homocysteine levels. Atherosclerosis 175: 69-75, 2004.

RODGERS GM, KANE WH: Activation of endogenous factor $\mathrm{V}$ by a homocysteine-induced vascular endothelial cell activator. J Clin Invest 77: 1909-1916, 1986.

RYNINGEN A, HOLMSEN H: Biochemistry of platelet activation. In: Platelet Physiology and Pharmacology. H GUNDU, R RAO (eds), Kluwer Academic Publishers, Norwell, 1999, pp 1-22.

SAULS DL, WOLBERG AS, HOFFMAN M: Elevated plasma homocysteine leads to alterations in fibrin clot structure and stability: Implications for the mechanism of thrombosis in hyperhomocysteinemia. $J$ Thromb Haemost $\mathbf{1}$ : 300-306, 2003.

SAULS DL, LOCKHART E, WARREN ME, LENKOWSKI A, WILHELM SE, HOFFMAN M: Modification of fibrinogen by homocysteine thiolactone increases resistance to fibrinolysis: a poptential mechanism of the thrombotic tendency in hyperhomocysteinemia. Biochem 45: 2480-2487, 2006.

SAULS DL, ARNOLD EK, BELL CW, ALLEN JC, HOFFMAN M: Pro-thrombotic and pro-oxidant effects of dietinduced hyperhomocysteinemia. Thromb Res 120: 117-126, 2007. 
SIGNORELLO MG, PASCALE R, LEONCINI G: Effect of homocysteine on arachidonic acid release in human platelets. Eur J Clin Invest 32: 279-284, 2002.

SIGNORELLO MG, VIVIANI GL, ARMANI U, CERONE R, MINNITI G, PIANA A, LEONCINI G: Homocysteine, reactive oxygen species and nitric oxide in type 2 diabetes mellitus. Thromb Res 120: 607-613, 2007.

STAMLER JS, OSBORNE JA, JARAKI O, RABBANI LE, MULLINS M, SINGEL D, LOSCALZO J: Adverse vascular effects of homocysteine are modulated by endothelium-derived relaxing factor and related oxides of nitrogen. J Clin Invest 91: 308-318, 1993.

THAMBYRAJAH J, TOWNEND JN: Homocysteine and atherothrombosis - mechanisms for injury. Eur Heart $J$ 21: 967-974, 2000.

UHLEMANN ER, TENPAS JH, LUCKY AW, SCHULMAN JD, MUDD SH, SHULMAN NR: Platelet survival and morphology in homocystinuria due to cystathionine synthase deficiency. $N$ Engl J Med 295: 1283-1286, 1976.

UNDAS A, WILLIAMS EB, BUTENAS S, ORFEO T, MANN KG: Homocysteine inhibits inactivation of factor Va by activated protein c. $J$ Biol Chem 276: 4389-4397, 2001.

UNDAS A, BROZEK J, JANKOWSKI M, SIUDAK Z, SZCZEKLIK A, JAKUBOWSKI H: Plasma homocysteine affects fibrin clot permeability and resistance to lysis in human subjects. Arterioscler Thromb Vasc Biol 26: 1397-1404, 2006.

UNDAS A, STEPIEN E, PLICNER D, ZIELINSKI L, TRACZ W: Elevated total homocysteine is associated with increased platelet activation at the site of microvascular injury: effects of folic acid administration. $J$ Thromb Haemost 5: 1070-1072, 2007.

WACHOWICZ B, OLAS B, ZBIKOWSKA HM, BUCZYŃSKI A: Generation of reactive oxygen species in blood platelets. Platelets 13: 175-182, 2002.

WU KK: Platelet activation mechanisms and markers in arterial thrombosis. J Intern Med 239: 17-34, 1996.

YANG X, GAO Y, ZHOU J, ZHEN Y, YANG Y, WANG J, SONG L, LIU Y, XU H, CHEN Z, HUI R: Plasma homocysteine thiolactone adducts associated with risk of coronary heart disease. Clin Chim Acta 364: 230-234, 2006. 